\title{
Front Matter: Volume 7676
}

, "Front Matter: Volume 7676," Proc. SPIE 7676, Sensing for Agriculture and Food Quality and Safety II, 767601 (6 May 2010); doi: 10.1117/12.867151

SDIE Event: SPIE Defense, Security, and Sensing, 2010, Orlando, Florida, United SPIE. States 


\section{PROCEEDINGS OF SPIE}

\section{Sensing for Agriculture and Food Quality and Safety II}

Moon S. Kim

Shu-I Tu

Kaunglin Chao

Editors

6-7 April 2010

Orlando, Florida, United States

Sponsored and Published by

SPIE

Volume 7676 
The papers included in this volume were part of the technical conference cited on the cover and title page. Papers were selected and subject to review by the editors and conference program committee. Some conference presentations may not be available for publication. The papers published in these proceedings reflect the work and thoughts of the authors and are published herein as submitted. The publisher is not responsible for the validity of the information or for any outcomes resulting from reliance thereon.

Please use the following format to cite material from this book:

Author(s), "Title of Paper," in Sensing for Agriculture and Food Quality and Safety II, edited by Moon S. Kim, Shu-I Tu, Kaunglin Chao, Proceedings of SPIE Vol. 7676 (SPIE, Bellingham, WA, 2010) Article CID Number.

ISSN 0277-786X

ISBN 9780819481405

Published by

SPIE

P.O. Box 10, Bellingham, Washington 98227-0010 USA

Telephone +1 3606763290 (Pacific Time) · Fax +1 3606471445

SPIE.org

Copyright (C) 2010, Society of Photo-Optical Instrumentation Engineers

Copying of material in this book for internal or personal use, or for the internal or personal use of specific clients, beyond the fair use provisions granted by the U.S. Copyright Law is authorized by SPIE subject to payment of copying fees. The Transactional Reporting Service base fee for this volume is $\$ 18.00$ per article (or portion thereof), which should be paid directly to the Copyright Clearance Center (CCC), 222 Rosewood Drive, Danvers, MA 01923. Payment may also be made electronically through CCC Online at copyright.com. Other copying for republication, resale, advertising or promotion, or any form of systematic or multiple reproduction of any material in this book is prohibited except with permission in writing from the publisher. The CCC fee code is 0277-786X/10/\$18.00.

Printed in the United States of America.

Publication of record for individual papers is online in the SPIE Digital Library.

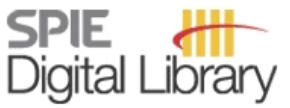

SPIEDigitalLibrary.org

Paper Numbering: Proceedings of SPIE follow an e-First publication model, with papers published first online and then in print and on CD-ROM. Papers are published as they are submitted and meet publication criteria. A unique, consistent, permanent citation identifier (CID) number is assigned to each article at the time of the first publication. Utilization of CIDs allows articles to be fully citable as soon they are published online, and connects the same identifier to all online, print, and electronic versions of the publication. SPIE uses a six-digit CID article numbering system in which:

- The first four digits correspond to the SPIE volume number.

- The last two digits indicate publication order within the volume using a Base 36 numbering system employing both numerals and letters. These two-number sets start with 00, 01, 02, 03, 04, $05,06,07,08,09,0 A, 0 B \ldots 0 Z$, followed by 10-1Z, 20-2Z, etc.

The CID number appears on each page of the manuscript. The complete citation is used on the first page, and an abbreviated version on subsequent pages. Numbers in the index correspond to the last two digits of the six-digit CID number. 


\section{Contents}

vii Conference Committee

\section{SESSION $1 \quad$ NIR SENSING}

767602 Influence of temperature on visible and near-infrared spectra and the predictive ability of multivariate models [7676-01]

L. Xie, Y. Ying, T. Sun, H. Xu, Zhejiang Univ. (China)

767603 Near-infrared hyperspectral imaging for quality analysis of agricultural and food products [7676-02]

C. B. Singh, D. S. Jayas, J. Paliwal, Univ. of Manitoba (Canada); N. D. G. White, Agriculture and Agri-Food Canada (Canada)

767605 Food quality assessment by NIR hyperspectral imaging [7676-04]

M. B. Whitworth, S. J. Millar, A. Chav, Campden BRI (United Kingdom)

$767606 \mathrm{UV} / \mathrm{visible} /$ near-infrared reflectance spectroscopic determination of cotton fiber and trash content in lint cotton waste [7676-05]

Y. Liu, G. R. Gamble, D. Thibodeaux, USDA Agricultural Research Service (United States)

767607 Damage and quality assessment in wheat by NIR hyperspectral imaging [7676-06]

S. R. Delwiche, M. S. Kim, USDA Agricultural Research Service (United States); Y. Dong, Univ. of Minnesota (United States)

\section{SESSION 2 OPTICAL SENSING}

767608 Detection of organic residues on food processing equipment surfaces by spectral imaging method [7676-07]

J. Qin, W. Jun, M. S. Kim, K. Chao, USDA Agricultural Research Service (United States)

$7676 \mathrm{OB}$ Effects of muscle structures on two-dimensional reflectance in beef muscles [7676-10]

G. Yao, Univ. of Missouri, Columbia (United States)

\section{SESSION 3 HYPERSPECTRAL IMAGING FOR FOOD EVALUATION}

7676 OD Single aflatoxin contaminated corn kernel analysis with fluorescence hyperspectral image [7676-13]

H. Yao, Z. Hruska, R. Kincaid, A. Ononye, Mississippi State Univ. (United States); R. L. Brown,

T. E. Cleveland, USDA Agricultural Research Service (United States)

$7676 \mathrm{OE}$ Calibration of a fluorescence hyperspectral imaging system for agricultural inspection and detection [7676-14]

A. E. Ononye, H. Yao, Z. Hruska, R. Kincaid, Mississippi State Univ. (United States) 
7676 OF Classification of fecal contamination on leafy greens by hyperspectral imaging [7676-15] C.-C. Yang, W. Jun, M. S. Kim, K. Chao, USDA Agricultural Research Service (United States); S. Kang, Rural Development Administration (Korea, Republic of); D. E. Chan, A. Lefcourt, USDA Agricultural Research Service (United States)

\section{SESSION 4 ONLINE HYPERSPECTRAL APPLICATION}

$76760 \mathrm{G}$ Characterization of the optical properties of normal and defective pickling cucumbers and whole pickles [7676-17]

R. Lu, USDA Agricultural Research Service (United States); D. P. Ariana, H. Cen, Michigan State Univ. (United States)

7676 ol Line-scan hyperspectral imaging for real-time poultry fecal detection [7676-19]

B. Park, S.-C. Yoon, W. R. Windham, K. C. Lawrence, G. W. Heitschmidt, M. S. Kim, K. Chao, USDA Agricultural Research Service (United States)

$76760 \mathrm{~J}$ Development of real-time line-scan hyperspectral imaging system for online agricultural and food product inspection [7676-20]

S. C. Yoon, B. Park, K. C. Lawrence, W. R. Windham, G. W. Heitschmidt, USDA Agricultural Research Service (United States)

\section{SESSION 5 BIOSENSORS AND PATHOGEN DETECTION}

7676 OK Rapid detection of total viable count of chilled pork using hyperspectral scattering technique [7676-21]

Y. Peng, F. Tao, Y. Li, W. Wang, J. Chen, J. Wu, S. Dhakal, China Agricultural Univ. (China)

$7676 \mathrm{OL} \quad$ Biophotonics determination of 6-benzylaminopurine (6-BAP) plant growth regulator using OFRR biosensor [7676-22]

G. Yang, S. Kang, K. Lee, G. Kim, J. Son, C. Mo, Rural Development Administration (Korea, Republic of)

$76760 \mathrm{M}$ Development of highly sensitive handheld device for real-time detection of bacteria in food [7676-23]

K. Zhang, A. Zhang, L. Fu, B. A. Chin, Z.-Y. Cheng, Auburn Univ. (United States)

7676 ON Micro-fabricated wireless biosensors for the detection of S. typhimurium in liquids [7676-24] S. Li, M. L. Johnson, Auburn Univ. (United States); Y. Li, H. Chen, Taiyuan Univ. of Science and Technology (China); I. Banerjee, I.-H. Chen, J. M. Barbaree, Z.-Y. Cheng, B. A. Chin, Auburn Univ. (United States)

767600 Near-infrared microscopic methods for the detection and quantification of processed by-products of animal origin [7676-25] O. Abbas, J. A. Fernández Pierna, P. Dardenne, V. Baeten, Walloon Agricultural Research Ctr. (Belgium) 
7676 OP Remote sensing of canopy dynamics and biochemical variables estimation of fodder crops [7676-26]

S. K. Rai, S. K. Das, A. K. Rai, Indian Grassland and Fodder Research Institute (India)

POSTER SESSION

7676 OS Spatial variation of water and soil erosion in Donghe basin based on SWAT model [7676-28] A. Liu, China Land Surveying and Planning Institute (China); J. Chen, The Institute of Geographical Sciences and Natural Resources (China); J. Wang, China Land Surveying and Planning Institute (China); Z. Liu, Chinese Academy of Surveying and Mapping (China)

7676 OT Technical system of land survey and monitoring and its future schemes in China [7676-29] J. Wang, China Land Surveying and Planning Institute (China) and Peking Univ. (China); A. Liu, China Land Surveying and Planning Institute (China); S. Li, Peking Univ. (China); Y. Chen, The Hong Kong Polytechnic Univ. (Hong Kong, China)

$76760 \mathrm{U}$ The development of the geographic image cognition approach on studying land degradation [7676-30]

J. Wang, China Land Surveying and Planning Institute (China) and The Hong Kong Polytechnic Univ. (Hong Kong, China); Y. Chen, The Hong Kong Polytechnic Univ. (Hong Kong, China); A. Liu, T. He, C. Lv, China Land Surveying and Planning Institute (China)

7676 OV Real-time near-infrared spectroscopic inspection system for adulterated sesame oil [7676-32]

S. Kang, K. Lee, J. Son, Rural Development Administration (Korea, Republic of); M. S. Kim, USDA Agricultural Research Service (United States)

7676 OW On-line determination of pork color and intramuscular fat by computer vision [7676-33] Y.-T. Liao, Y.-X. Fan, X.-Q. WU, L. Xie, F. Cheng, Zhejiang Univ. (China)

7676 0X Quantitative analysis and detection of adulteration in pork using near-infrared spectroscopy [7676-34]

Y. Fan, F. Cheng, L. Xie, Zhejiang Univ. (China)

Author Index 
Downloaded From: https://www.spiedigitallibrary.org/conference-proceedings-of-spie on 26 Apr 2023

Terms of Use: https://www.spiedigitallibrary.org/terms-of-use 


\title{
Conference Committee
}

\author{
Symposium Chair
}

Michael T. Eismann, Air Force Research Laboratory (United States)

Symposium Cochair

William Jeffrey, HRL Laboratories, LLC (United States)

Conference Chairs

Moon S. Kim, USDA Agricultural Research Service (United States)

Shu-I Tu, USDA Agricultural Research Service (United States)

Kaunglin Chao, USDA Agricultural Research Service (United States)

Program Committee

Arjun Bangalor, Chemlmage Corporation (United States)

Arun K. Bhunia, Purdue University (United States)

Suming Chen, National Taiwan University (Taiwan)

Byoung-Kwan Cho, Chungnam National University (Korea, Republic of)

Stephen R. Delwiche, USDA Agricultural Research Service (United States)

Ki-Bok Kim, Korea Research Institute of Standards and Science (Korea, Republic of)

Naoshi Kondo, Kyoto University (Japan)

Kurt C. Lawrence, USDA Agricultural Research Service (United States)

Kang-Jin Lee, Rural Development Administration (Korea, Republic of)

Alan M. Lefcourt, USDA Agricultural Research Service (United States)

Renfu Lu, USDA Agricultural Research Service (United States)

Bosoon Park, USDA Agricultural Research Service (United States)

Yankun Peng, China Agricultural University (China)

Yang Tao, University of Maryland, College Park (United States)

Gang Yao, University of Missouri, Columbia (United States)

Yibin Ying, Zhejiang University (China)

Session Chairs

$1 \quad$ NIR Sensing

Sukwon Kang, Rural Development Administration (Korea, Republic of)

2 Optical Sensing

Gang Yao, University of Missouri, Columbia (United States) 
3 Hyperspectral Imaging for Food Evaluation

Renfu Lu, USDA Agricultural Research Service (United States)

4 Online Hyperspectral Application

Bosoon Park, USDA Agricultural Research Service (United States)

5 Biosensors and Pathogen Detection

Bryan A. Chin, Auburn University (United States)

$6 \quad$ Remote Sensing

Renfu Lu, USDA Agricultural Research Service (United States) 